\title{
Proportionate dwarfism in a painting of Rodrigo de Villandrando (1620)
}

\author{
C. M. Oranges ${ }^{1}$
}

Received: 11 June 2015 / Accepted: 19 June 2015 / Published online: 2 July 2015

(C) Italian Society of Endocrinology (SIE) 2015

Rodrigo de Villandrando (Madrid, 1588-Madrid, 1623) Court of Spain in the XVII Century.

This picture, titled "El Príncipe Felipe y el enano Miguel Soplillo", is an oil on canvas painting dated 1620, representing the Prince Philip, later Philip IV of Spain, with his personal attendant, Miguel Soplillo, affected by proportionate dwarfism.

The work stands in the Spanish courtly painting tradition of representing the Court dwarfs, mostly employed as personal attendants, servants or entertainers [1]. Soplillo came to the Spanish Court from the Flanders as a gift of the Princess Isabel Clara Eugenia, aunt of the Prince. The gesture of the Prince of laying his right hand on the head of the dwarf has been interpreted as a message of benevolence and piety to the servant, as a symbol of the royal protection that would be extended to his future subjects [2]. was a chamber's painter who worked at the King Philip III

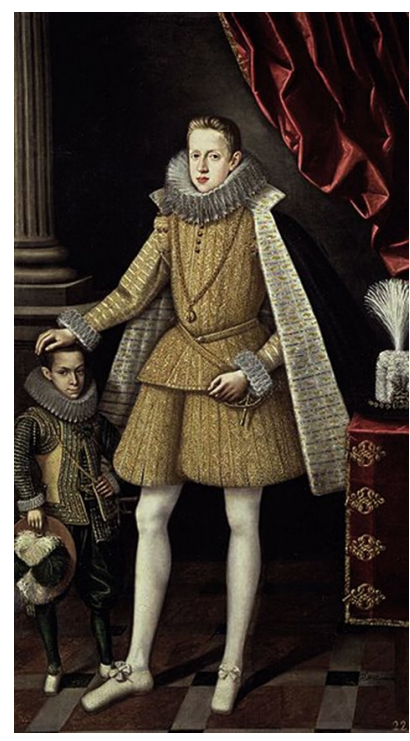

The picture is exposed at the Prado Museum in Madrid.

Compliance with ethical standards

Conflict of interest None.

Ethical approval This paper does not contain any studies with human participants or animals performed by the author.

Informed consent No informed consent.

\section{References}

1. Martino E (1999) "The dwarf" (Sebastiano de Morra). Velazquez. Sevilia (1599)-Madrid (1660), Spain. J Endocrinol Invest 22(7):581

C. M. Oranges
studioranges $22 @$ gmail.com

1 Plastic, Reconstructive and Aesthetic Surgery Service, Lame Multispecialist Medical Center, Bologna, Italy
2. Ruiz L (2006) El retrato español en el Prado. Del Greco a Goya, Museo Nacional del Prado, Madrid, pp 68-69 